\title{
EFFECTS OF MATERNAL EXPOSURE TO A LOW DOSE OF DIETHYLSTILBESTROL ON SEXUAL DIMORPHIC NUCLEUS VOLUME AND MALE REPRODUCTIVE SYSTEM IN RAT OFFSPRING
}

\author{
Masako YAMAMOTO ${ }^{1}$, Mitsuyuki SHIRAI ${ }^{2}$, Aya TAMURA ${ }^{1}$, Tetsuo KOBAYASHI ${ }^{1}$, \\ Shinnya KOHARA ${ }^{1}$, Masaru MURAKAMI ${ }^{3}$ and Kazuyoshi ARISHIMA ${ }^{1}$ \\ ${ }^{l}$ Department of Anatomy II, ${ }^{2}$ Department of Veterinary Pharmacology, \\ ${ }^{3}$ Department of Molecular Biology, Azabu University, School of Veterinary Medicine, \\ 1-17-71 Fuchinobe, Sagamihara, Kanagawa 229-8501, Japan
}

(Received August 2, 2004; Accepted November 9, 2004)

\begin{abstract}
Diethylstilbestrol (DES) was administered subcutaneously at $0.5,1.5$ or $4.5 \mu \mathrm{g} / \mathrm{kg} / \mathrm{day}$ (DES 0.5, 1.5 and 4.5 groups, respectively) to pregnant SD rats daily on days 7-21 of gestation, to investigate its effects on the development and functions of the reproductive system in their male offspring. Of the 10 pregnant rats in the DES 4.5 group, only 1 delivered, and this rat could not suckle the pups. Rat pups in the DES 0.5 and 1.5 groups were autopsied at 1, 3, 6 and 15 weeks after birth. The testosterone concentrations in the DES 1.5 and 0.5 groups at 6 weeks were significantly decreased and the plasma LH concentrations were not altered. In the DES 1.5 group, DES treatment did not change the volume of the sexually dimorphic nucleus in the preoptic area (SDN-POA) in the male offspring, although this dose of DES increased the volume of SDN-POA in female offspring. The DES treatment altered frequencies in the cycles of the seminiferous tubules, and suppressed histological maturation in the epididymis and the prostate weight. These observations indicate that prenatally administered DES impairs testicular endocrine function continuously as well as putuitary function, but the induced low level of testosterone disrupts spermatogensis and permanently inhibits the morphological development of epididymis and prostate.
\end{abstract}

KEY WORDS: DES, Rat, Testis, SDN-POA, Spermatogenesis, Epididymis

\section{INTRODUCTION}

Diethylstilbestrol (DES), a synthetic nonsteroidal estrogen, was widely used as one of the best medications for preventing threatened abortion in the late 1940 s and 1950s. However, Kaplan (1959) first reported that DES may have affected the normal development of the reproductive system in male offspring. Since then, many reports have appeared on the undesirable effects of DES in the reproductive system of men and women (Herbst and Bern, 1981) and in experimantal animals (McLachlan et al., 1975; Arai et al., 1983). Numerous studies have used prenatal or postnatal exposure to DES, however, mostly in high doses ranging from to 10 to $300 \mu \mathrm{g} / \mathrm{kg}$, to induce gross adverse changes in the developing male reproductive system (McLachlan et al., 1975; Sharpe et al., 1995; Haavisto et al., 2001; McKinnell et al., 2001). We recently reported a new event of the prenatal administration of a low dose of DES $(1.5 \mu \mathrm{g} / \mathrm{kg} / \mathrm{day})$ irreversibly stimulating thyroid function (Yamamoto et al., 2003). Moreover, we demonstrated that a low dose of DES has an inhibitory effect on plasma testosterone concentration in male offspring and a promoting effect on folliclular maturation in female offspring at puberty. This study examined the effects of DES on the hormone concentration and female reproductive system at weaning and puberty, but failed to clarify the effects of prenatal administration of DES on testicular function at maturation.

The perinatal environment has been shown to affect neuroanatomy and neuroendocrinology. A morphological marker of sexual differentiation, the sexually dimorphic nucleus in the preoptic area (SDN- 


\section{YAMAMOTO et al.}

POA) of the hypothalamus, which is normally larger in male rats than in female rats, is sensitive to hormonal influence during critical periods of development (Gorski et al., 1978). When the hypothalamus becomes masculinized, the pattern of gonadotropin secretion at puberty becomes masculinized. It would elucidate the mechanism of the inhibitory effects of DES on the male reproductive system to investigate the effects of DES-induced low levels of testosterone on the sexual differentiation of the central nervous system.

Although the administration of DES in the neonatal period has been reported to induce impaired spermatogenesis (Sharpe et al., 1995, 1998; Atanassova et al., 1999, 2000; Goyal et al., 2001, 2003; Mckinnell et al., 2001) and retarded development of the epididymis (Atanassova et al., 1999, 2001; Mckinnell et al., 2001), there have been few reports on its effects of prenatal administration on these endpoints (Traina et al., 2003). In this study, we aimed to investigate in more detail the effects of the prenatal administration of different low doses of DES on the reproductive system by examining the sexual differentiation of the central nervous system, the functions of the pituitary gland, and sex hormone levels, spermatogenesis, and epididymal development in mature male rats.

\section{MATERIALS AND METHODS}

\section{Animals and treatments}

Sprague-Dawley rats (Japan SLC, Japan) were given a commercial diet (CE-2, CLEA, Tokyo, Japan) and water, both ad libitum. Females were mated with males overnight and were examined the next morning for the presence of sperm in the vaginal smear. The day on which sperm was detected was counted as day 0 of gestation. Pregnant rats were housed individually and maintained in 12/12 hr light-dark cycle at room temperature of $21 \pm 2{ }^{\circ} \mathrm{C}$ and humidity of $55 \pm 5 \%$. Pregnant rats were divided into three groups. The rats in each group were treated daily subcutaneously with DES (Sigma Chemical Co., St. Louis, MO, USA) at $0.5,1.5$ or $4.5 \mu \mathrm{g} / \mathrm{kg} /$ day (DES 0.5, DES 1.5 and DES 4.5 groups, respectively) dissolved in corn oil (tocopherol-stripped, ICN Biomedicals Inc.,USA), or corn oil alone (control group) on days 7-21 of gestation. The volume of a single dose ranged from 0.2-0.4 ml.

Four days after birth, pups were controlled to 4 males and 4 females in each litter. There were 10 litters per group. The pups were kept with their natural mothers until weaning on day 21. Rats were autopsied under ether anesthesia at postnatal weeks 1, 3, 6 and 15, and the testis, epidydimis and prostate from male pups were dissected and weighed. In addition, the brain of male and female offspring were removed and subjected to determination of the volume of SDN-POA. In general, pregnant rats delivered on the afternoon of day 21 of gestation.

The study described in this paper was carried out in accordance with the Azabu University Animal Experiment Guidelines.

\section{Hormonal measurement}

A blood sample was collected from the abdominal artery of each animal prior to necrospy. The blood samples were centrifuged at $4^{\circ} \mathrm{C}$, and the plasma stored at $-80^{\circ} \mathrm{C}$ until assay. The concentration of plasma testosterone was measured by radioimmunoassay using the $\left[{ }^{125} \mathrm{I}\right]$ total testosterone assay kit (Diagnostic Products Coop., Los Angeles, USA). The sensitivity was determined to be $4 \mathrm{ng} / \mathrm{dl}$. The concentrations of pituitary hormones, LH and FSH were measured by the rat luteinizing hormone enzyme immunoassay system and the rat follicle stimulating hormone enzyme immunoassay system (Amersham Pharmacia Biotech, USA), respectively. The sensitivity was determined to be $0.1 \mathrm{ng} / \mathrm{ml}$, and $8.66 \mathrm{ng} / \mathrm{ml}$, respectively.

\section{RNA extraction}

Total RNA from the pituitary gland of male offspring at 6 weeks was extracted using Isogen (Nippon Gene Co., Japan) according to the manufacturer's protocol. The subsequent isolation involved chloroform extraction, isopropanol precipitation, and washing in $70 \%$ ethanol. The concentration of total RNA was determined by measuring the optimal density at 260 $\mathrm{nm}$ and $280 \mathrm{~nm}$.

\section{Semiquantitative RT-PCR}

PCR amplification from reverse-transcribed cDNA was performed with the following primers: gonadotropin-releasing hormone $(\mathrm{GnRH})$ receptor (sense, 5'-CTT TGC GGG ACC ACA GT-3'; antisense, 5'-TCA GCC GTG CTC TTG GGA TA3')(Roth et al., 2001). The reactions were performed according to the manufacturer's instructions for the SuperScript one-step RT-PCR (Invitrogen, USA). The total volume of $50 \mu \mathrm{l}$ of the reaction mixture contained 100 ng RNA, 10 nM sense and anti-sense primers, tag Mix (containing reverse transcriptase and DNA polymerase) and $1 \mathrm{X}$ reaction mix. cDNA synthesis and pre-denaturation were performed with one cycle of $50^{\circ} \mathrm{C}$ for $30 \mathrm{~min}$ and $94^{\circ} \mathrm{C}$ for $2 \mathrm{~min}$. The mixture was 
Effects of DES on the development of the male reproductive system.

then amplified for 33 cycles with a Thermal cycler (BIO-RAD), each cycle consisting of a denaturation step $\left(94.0^{\circ} \mathrm{C}, 1 \mathrm{~min}\right)$, an annealing step $\left(60^{\circ} \mathrm{C}, 1 \mathrm{~min}\right)$, and an elongation step $\left(75.0^{\circ} \mathrm{C}, 2 \mathrm{~min}\right)$, with a final 4 min elongation after the last cycle. The expected GnRH receptor amplification product based on these primers was $281 \mathrm{bp}$. In addition, to provide an appropriate internal control, coamplification of a $246 \mathrm{bp}$ fragment of the $\beta$-actin was carried out in each sample using the primer pair of sense, 5'-CAG CCT TCC TTC CTG GGT ATG3'; antisense, 5'-TAG AGC CAC CAA TCC ACA CAG-3' (Walker et al., 1999).

Following PCR, the amplified DNA was separated by electrophoresis in a $2.5 \%$ agarose gel with an appropriate molecular weight marker (BIO-RAD). Gels were stained with ethidium bromide, photographed using a Polaroid camera, and the intensity of the band digitized using an EPSON scanner. The signal intensities were measured in five individual animals and two independent RT for each sample. The digitized signals were imported into NIH Image and the average OD of each band was measured, and normalized to $\beta$ actin to obtain the ratio of $\mathrm{GnRH}$ receptor to $\beta$-actin for each sample.

\section{Morphological analysis of SDN-POA}

The $4 \%$ paraformaldehyde-fixed brains from male and female offspring at 3 and 6 weeks after birth were routinely dehydrated, embedded in paraplast, and sectioned serially at $8 \mu \mathrm{m}$. Sections were stained with Bodian's staining. The area of SDN-POA was measured with an image analyzing apparatus (Olympus Industry Co., Japan). The total volume of the SDNPOA was calculated as follows: the total volume $\left(\mu \mathrm{m}^{3}\right)$ $=$ the sum of areas of SDN-POA $\left(\mu \mathrm{m}^{3}\right) \times 8 \mu \mathrm{m}$.

\section{Spermatogenesis}

The Bouin's fixed testes at 6 and 15 weeks were dehydrated, embedded in paraffin, and sectioned at 5 $\mu \mathrm{m}$. Sections were stained with periodic acid-schiff and counter stained with hematoxylin. Seminiferous tubules were staged according to the criteria published by Hess (1990). Five hundred tubules per testis were classified into the following groups: stage I, II/III, IV, V, VI, VII, VIII, IX, X, XI, XII, XIII and XIV. The values were expressed as the proportion (\%) of the number of seminiferous tubules in each stage to total tubules.

\section{Morphometry of epididymis}

The initial segment, caput proximal, cauda prox- imal and cauda distal regions of the Bouin's fixed epididymides at 3,6 and 15 weeks were dehydrated and embedded in paraffin (Fig. 1, according to Hermo et al., 1992). The cross sections from each region were stained with hematoxylin and eosin. The tubular diameter (basal lamina to basal lamina), epithelial height and luminal diameter of 40 tubules from each animal were measured with a micrometer set in an ocular lens of a microscope.

\section{Statistical analysis}

Mean values and standard errors were calculated for the organ weights, hormone concentrations, and morphometrical parameters. Statistical analyses of data were made by means of Student's $t$-test (Steel and Torrie, 1980). Values of $\mathrm{p}<0.05$ were considered significant.

\section{RESULTS}

\section{General observations}

All 10 pregnant rats in the DES 0.5, DES 1.5 and control groups delivered pups. In the DES 4.5 group, all 10 pregnant rats began to bleed from the second trimester, and only 1 delivered, but this rat could not suckle the pups. Thus, only the data on the control, DES 0.5 and DES 1.5 groups are shown below.

Table 1 shows the body weight and the weight of various organs of the male pups in each group at autopsy. The administration of $1.5 \mu \mathrm{g} / \mathrm{kg} /$ day of DES significantly decreased the body weight at 3 and 15 weeks after birth. The testicular weight was significantly decreased but the relative weight of the testis did not change in the DES 1.5 group at 6 weeks after birth. The epididymis weight was significantly decreased but the relative weight of the epididymis did not change in the DES 1.5 group at 15 weeks after birth. The prostate weight was significantly decreased at 3, 6 and 15 weeks and the relative weight of the prostate was significantly decreased in the DES 1.5 group at 15 weeks after birth.

\section{Changes in plasma hormone concentrations}

Table 2 shows the results of the determination of plasma hormone concentrations. The plasma testosterone concentrations in the offspring at 3 weeks after birth were below the detection limits. At 6 weeks after birth, the plasma testosterone concentrations in the DES 0.5 and 1.5 groups were significantly decreased, but at 15 weeks the hormone levels had not changed. The plasma FSH concentration in the DES 1.5 group 
was significantly increased. The plasma LH level in the DES 1.5 group at 3 weeks was significantly increased.

\section{Effects on SDN-POA volume}

The volume of SDN-POA in the male and female offspring is represented in Table 3 . In all groups, the volume of SDN-POA of the male offspring was approximately 2 -fold larger than that of the female offspring. In the males, DES treatment did not alter the volume of SDN-POA. In the females, the volume in the DES 1.5 group was larger than that in the control group at 3 and 6 weeks.

\section{Effects on spermatogenesis}

Five hundred tubules per testis were classified into spermatogenesis stages (Fig. 2). At 6 weeks after birth, the percentage of stage I seminiferous tubules was significantly higher in the offspring from the DES
0.5 group than that in the offspring from the control group (Fig. 2). The proportion of stage IV seminiferous tubules was significantly higher in the DES 1.5 group than that in the DES 0.5 group. At 15 weeks after birth, the DES administration significantly increased the percentage of stage IV seminiferous tubules. The proportion of stage $\mathrm{V}$ seminiferous tubules was significantly higher in the DES 0.5 group than that in the control group. In the DES 1.5 group, the percentage of stage IX tubules was significantly lower than that in the control group, and the percentage of stage XI was significantly lower than that in the DES 0.5 group.

Pathological changes, such as pyknotic nuclei and occurrence of cell debris, were not detected in the seminiferous tubules from DES-treated groups at 6 and 15 weeks. In addition, there was no morphological appearance of damaged Leydig cells.

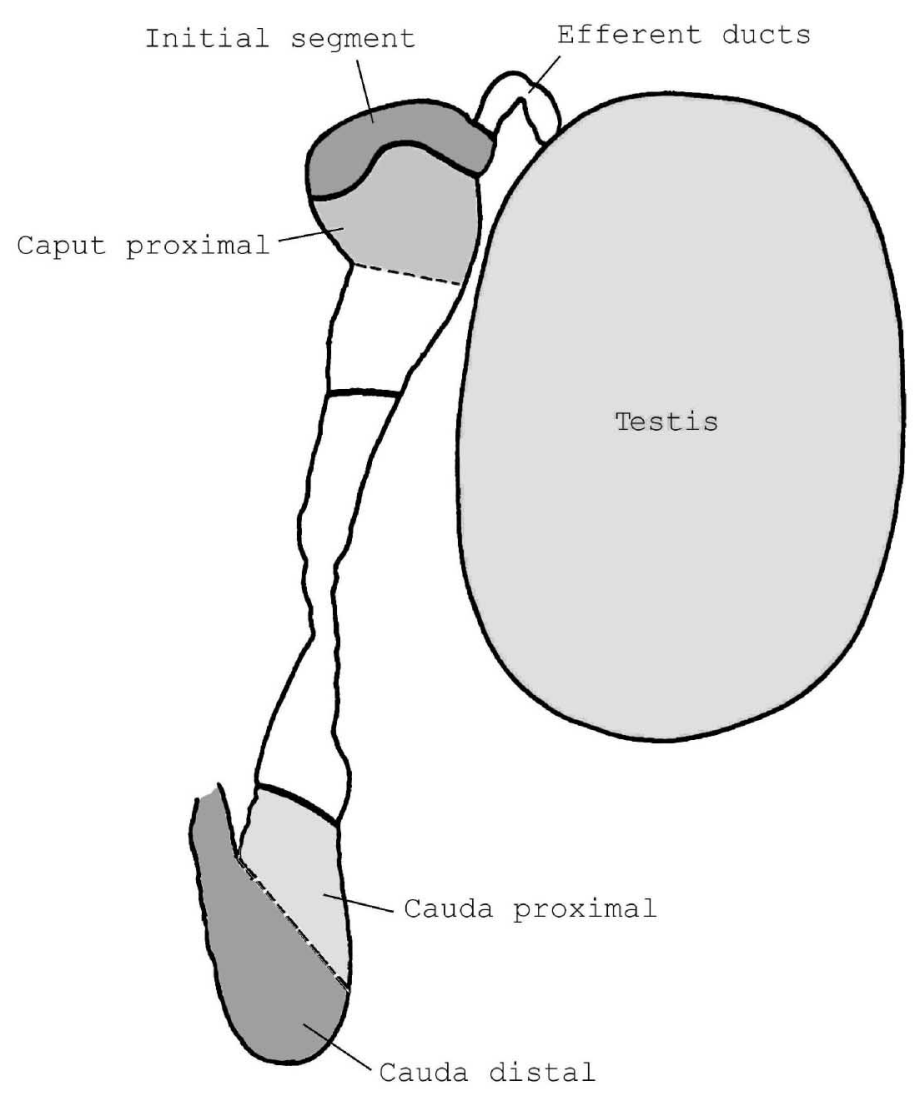

Fig. 1. Schematic representation of the epididymis. The epididymis was divided into various regions, the initial segment, caput proximal, cauda proximal and cauda distal areas, which were subjected to morphometrical analysis. 
Effects of DES on the development of the male reproductive system.

\section{Effects on epididymis}

The tubular diameter, epithelial height and luminal diameter in four regions of the epididymis were measured (Table 4). In the initial segment region of the epididymal tubules, the luminal diameter and tubular diameter in the DES 1.5 group at 3 weeks after birth were significantly smaller than those in the control group. In the caput proximal region, the epithelial height in the DES 1.5 group at 6 weeks after birth and the luminal diameter and tubular diameter at 15 weeks after birth were significantly smaller than those in the control group. In the cauda proximal region, the tubular diameter in the DES 1.5 group at 3 weeks after birth and the luminal diameter and tubular diameter at 15 weeks after birth were significantly smaller than those in the control group. In the cauda distal region, the luminal diameter and tubular diameter in the DES 1.5 group at 3 weeks after birth were significantly smaller than those in the control group.

\section{Effect on GnRH receptor mRNA expression in the pituitary.}

Using semiquantitative RT-PCR, we examined changes in the expression level of GnRH receptor mRNA in the pituitary of 6-week-old male rats after DES administration (Table 5), and found that its administration did not influence the expression of pituitary GnRH receptor mRNA.

\section{DISCUSSION}

In our previous study (Yamamoto et al., 2003), we determined the high level of DES $(15 \mu \mathrm{g} / \mathrm{kg} / \mathrm{day})$ considering Boylan's results (1978) that various doses of DES were treated s.c. to SD rat. That previous result (Yamamoto et al., 2003) showed that the administration of 15 (and not 1.5) $\mu \mathrm{g} / \mathrm{kg} /$ day of DES on the 7th through 21st days of pregnancy seriously impaired the maintenance of pregnancy, precluding childbirth. In this study, we used DES at a dose of $0.5,1.5$, or $4.5 \mu \mathrm{g} /$ $\mathrm{kg} / \mathrm{day}$, and found that $1.5 \mu \mathrm{g} / \mathrm{kg} /$ day was approximately the maximum possible dose for the period of

Table 1. Effects of prenatal exposure to DES on body weight and the weight of the testis, eipididymis and prostate.

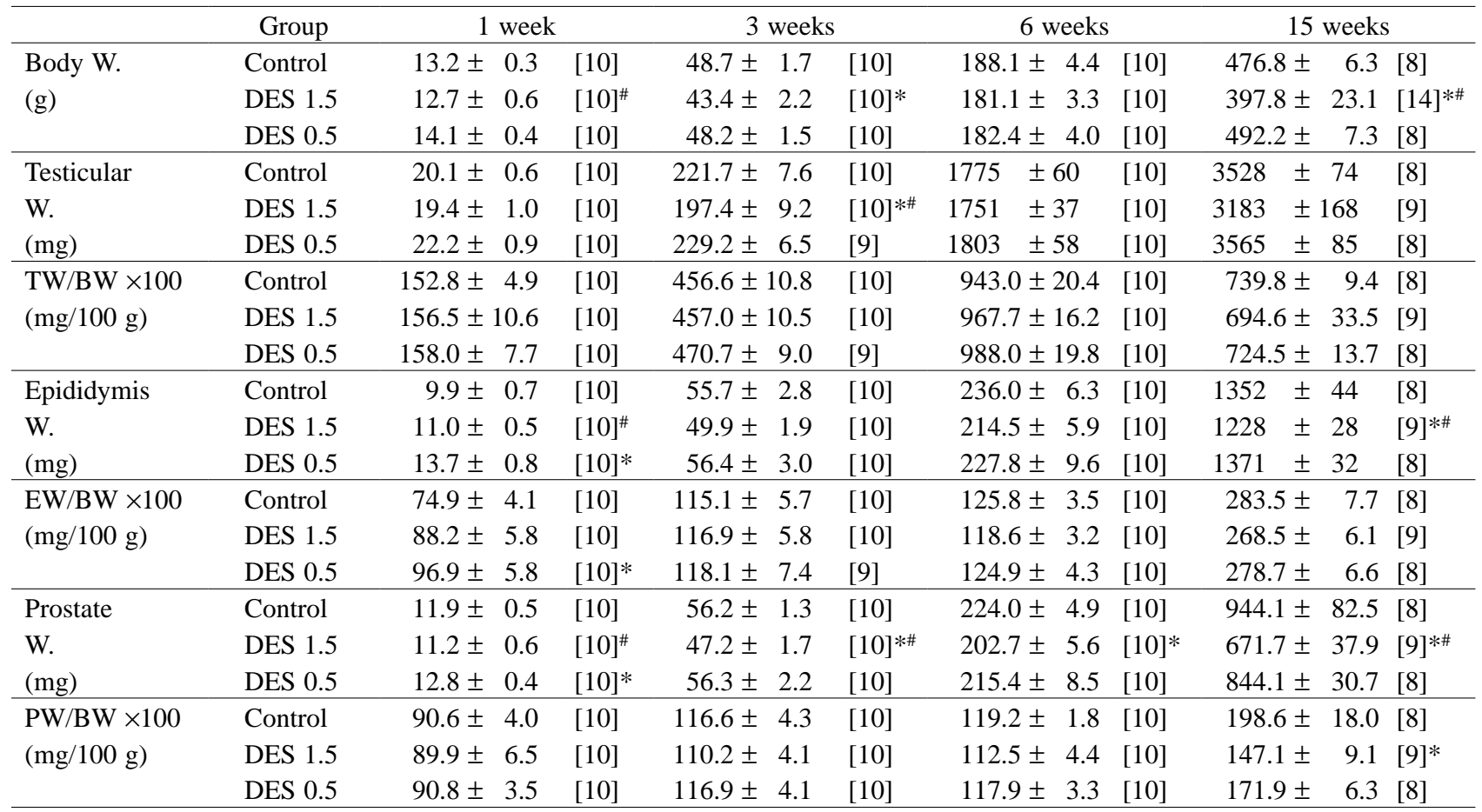

[ ] : No. of offspring

* : Significant difference from control values $(\mathrm{p}<0.05)$.

\# : Significant difference from DES 0.5 group $(\mathrm{p}<0.05)$. 
M. YAMAMOTO et al.

DES administration in this study.

The administration of DES to newborn or adult male rats has been reported to cause weight loss (Sharpe and Skakkebeak, 1993; Goyal et al., 2001). In this study, the DES 1.5 group showed marked weight loss at 15 weeks after birth, but the DES 0.5 group showed no weight loss, suggesting that DES reduces weight in a dose-dependent manner.

As in our previous study, the testosterone concentrations in the DES groups at 6 weeks after birth were decreased. When testicular testosterone secretion decreases, anterior pituitary LH acts on testicular Leydig cells to promote testosterone synthesis. However, in this study, LH concentrations did not significantly increase despite the marked decrease in the testosterone concentration in the DES groups at 6 weeks after birth. Although the testosterone assay kit used in this study failed to detect the hormone at 3 weeks after birth, since LH concentrations at 3 weeks after birth were increased with the administration of
DES in a dose-dependent manner, the testosterone levels at 6 weeks after birth suggest decreased testosterone levels at 3 weeks after birth. These results suggest that the prenatal exposure to DES altered pituitary function at 6 weeks, not at 3 weeks. Hence we determined the putuitary function via the hypothalamus at 6 weeks. The finding of no change in the expression level of GnRH receptor mRNA suggests that the sensitivity of the pituitary to instructions from the hypothalamus was impaired.

When SD rats received s.c. injections of DES (at a dose of $10 \mu \mathrm{g}, 1 \mu \mathrm{g}, 100 \mathrm{ng}, 10 \mathrm{ng}$ or $1 \mathrm{ng}$ per pup) during postnatal days 2-12, plasma testosterone levels decreased in the $10 \mu \mathrm{g}$ - and $1 \mu \mathrm{g}$-treated animals and LH levels were unaltered at adulthood (83-91 days of age)(Goyal et al., 2003). In the present study, the administration of the low dose of DES $(0.5$ and $1.5 \mu \mathrm{g} /$ $\mathrm{kg}$ /day) did not change the level of testosterone at 15 weeks after birth. Therefore, the prenatal exposure to DES severely impaired the testicular endocrine func-

Table 2. Effects of prenatal exposure to DES on plasma hormone concentrations in male offspring.

\begin{tabular}{|c|c|c|c|c|c|c|c|c|}
\hline Hormone & Group & \multicolumn{2}{|l|}{3 weeks } & \multicolumn{3}{|c|}{6 weeks } & \multicolumn{2}{|l|}{15 weeks } \\
\hline \multirow{3}{*}{$\begin{array}{c}\text { Testosterone } \\
\text { (ng/dl) }\end{array}$} & Control & nd & [8] & 51.4 & \pm 16.6 & [9] & $131.7 \pm 14.1$ & [8] \\
\hline & DES 1.5 & nd & {$[8]$} & 17.6 & \pm 7.3 & {$[10] *$} & $156.3 \pm 46.8$ & [9] \\
\hline & DES 0.5 & nd & [8] & 13.3 & \pm 7.8 & {$[10] *$} & $119.2 \pm 25.2$ & [8] \\
\hline \multirow{3}{*}{$\begin{array}{c}\text { FSH } \\
(\mathrm{ng} / \mathrm{ml})\end{array}$} & Control & $50.6 \pm 12.1$ & [6] & 41.1 & \pm 3.7 & [6] & $30.6 \pm 9.7$ & [7] \\
\hline & DES 1.5 & $49.1 \pm 6.7$ & [7] & 55.2 & \pm 3.3 & [7] $*$ & $29.3 \pm 7.7$ & [9] \\
\hline & DES 0.5 & $43.9 \pm 4.5$ & [7] & 45.9 & \pm 3.9 & [7] & $64.7 \pm 19.4$ & [8] \\
\hline \multirow{3}{*}{$\begin{array}{c}\mathrm{LH} \\
(\mathrm{ng} / \mathrm{ml})\end{array}$} & Control & $7.29 \pm 1.83$ & [6] & 3.19 & \pm 1.29 & {$[6]$} & $5.60 \pm 1.70$ & {$[8]$} \\
\hline & DES 1.5 & $13.42 \pm 1.21$ & [7] * & 5.01 & \pm 1.37 & [7] & $4.77 \pm 0.86$ & [9] \\
\hline & DES 0.5 & $12.01 \pm 1.60$ & [7] & 4.24 & \pm 1.03 & [7] & $5.10 \pm 1.14$ & [8] \\
\hline
\end{tabular}

nd : not detected

[ ] : No. of offspring

* : Significant difference from control group $(\mathrm{p}<0.05)$.

Table 3. Effects of prenatal exposure to DES on the volume of SDN-POA in male and female offspring.

\begin{tabular}{|c|c|c|c|c|c|}
\hline \multirow{3}{*}{$\frac{\text { sex }}{\text { male }}$} & \multirow{3}{*}{$\frac{\text { Group }}{\text { Control }}$} & \multicolumn{4}{|c|}{ Volume of SDN-POA $\left(\times \mathrm{mm}^{-3}\right)$} \\
\hline & & \multicolumn{2}{|c|}{6 weeks } & \multicolumn{2}{|c|}{15 weeks } \\
\hline & & $19.8 \pm 2.5$ & {$[5]^{\#}$} & $156.3 \pm 2.3$ & $[5]]^{\#}$ \\
\hline & DES 1.5 & $15.8 \pm 1.2$ & {$[5]^{\#}$} & $119.2 \pm 2.0$ & $[5]]^{\#}$ \\
\hline & DES 0.5 & $18.3 \pm 0.9$ & {$[5]^{\#}$} & $131.7 \pm 1.3$ & {$[5]^{\#}$} \\
\hline \multirow[t]{3}{*}{ female } & Control & $6.2 \pm 0.7$ & {$[5]$} & $7.3 \pm 0.5$ & [5] \\
\hline & DES 1.5 & $8.4 \pm 0.4$ & [5] * & $10.9 \pm 1.3$ & [5] * \\
\hline & DES 0.5 & $7.7 \pm 0.4$ & {$[5]$} & $9.0 \pm 0.6$ & {$[5]$} \\
\hline
\end{tabular}

[ ] : No. of samples

\# : Significant difference from different sex in the same group $(\mathrm{p}<0.05)$.

* : Significant difference from control group $(\mathrm{p}<0.05)$. 
Effects of DES on the development of the male reproductive system.
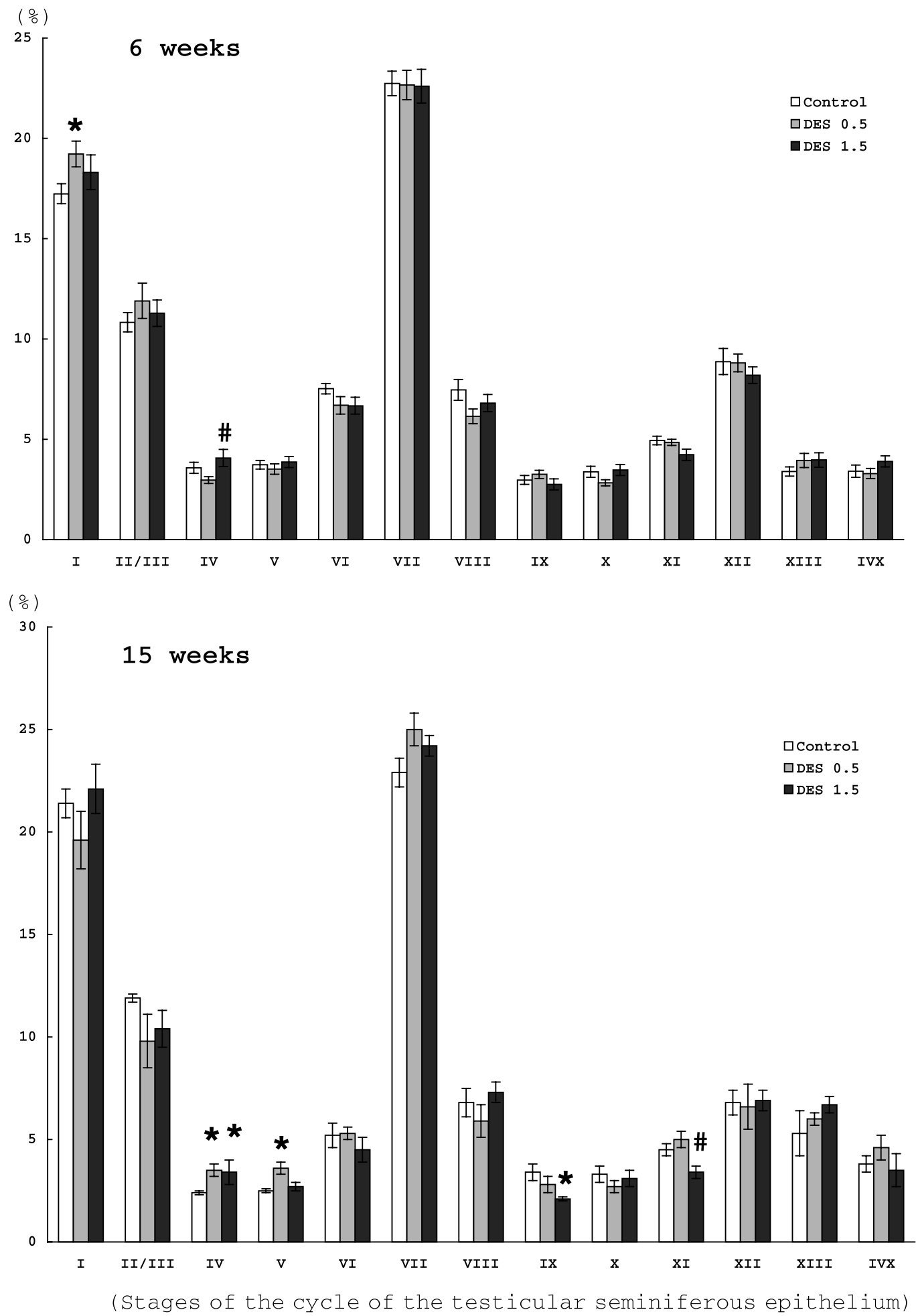

Fig. 2. Effects of prenatal exposure to DES on the stage frequencies in the cycle of seminiferous tubules at 6 and 15 weeks after birth. *:Significant difference from control group, $\mathrm{p}<0.05$. \#:Significant difference from DES 0.5 group, $\mathrm{p}<0.05$. $\mathrm{n}=10$ (6 weeks), 5 (15 weeks). 
M. YAMAMOTO et al.

tion compared to the postnatal exposure to DES. In addition, the inhibitory effect of the prenatally DES treatment on the testicular steroidogenesis is reversible. Further detailed studies are needed on the effects of DES on the testicular steroid synthesis system.

Sexual differentiation of the rat preoptic area depends on perinatal exposure to estrogen (Arnold and Gorski, 1984). Estrogen, derived from local aromatiza-

Table 4. Epithelial height, luminal diameter, and tubular diameter in different regions of the epididymis after maternal administration of DES.

\begin{tabular}{|c|c|c|c|c|c|c|c|}
\hline \multirow{4}{*}{$\begin{array}{l}\text { Initial segment } \\
\text { Epithelial height } \\
(\mu \mathrm{m})\end{array}$} & \multirow{3}{*}{$\begin{array}{l}\text { Group } \\
\text { Control }\end{array}$} & \multicolumn{2}{|c|}{3 weeks } & \multicolumn{2}{|c|}{6 weeks } & \multicolumn{2}{|c|}{15 weeks } \\
\hline & & & & & & & \\
\hline & & $19.8 \pm 0.5$ & [9] & $39.7 \pm 0.7$ & [8] & $34.2 \pm 2.7$ & [8] \\
\hline & DES 1.5 & $19.0 \pm 0.4$ & [10] & $36.9 \pm 1.7$ & [8] & $32.9 \pm 2.2$ & [8] \\
\hline & DES 0.5 & $19.8 \pm 0.8$ & [9] & $37.5 \pm 0.3$ & {$[8] *$} & $29.1 \pm 0.6$ & [8] \\
\hline \multirow{3}{*}{$\begin{array}{l}\text { Luminal diameter } \\
(\mu \mathrm{m})\end{array}$} & Control & $20.7 \pm 0.7$ & [9] & $68.3 \pm 0.8$ & [8] & $117.8 \pm 1.9$ & [8] \\
\hline & DES 1.5 & $18.0 \pm 0.3$ & [10] *\# & $65.8 \pm 3.4$ & [8] & $116.2 \pm 1.9$ & [8] \\
\hline & DES 0.5 & $20.0 \pm 0.5$ & [9] & $69.6 \pm 1.9$ & [8] & $118.1 \pm 2.6$ & [8] \\
\hline \multirow{3}{*}{$\begin{array}{l}\text { Tubular diameter } \\
(\mu \mathrm{m})\end{array}$} & Control & $60.5 \pm 1.2$ & [9] & $147.8 \pm 1.7$ & [8] & $186.4 \pm 4.8$ & [8] \\
\hline & DES 1.5 & $56.2 \pm 0.9$ & {$[10] *$} & $139.7 \pm 6.3$ & [8] & $182.1 \pm 4.9$ & [8] \\
\hline & DES 0.5 & $60.0 \pm 1.8$ & [9] & $144.7 \pm 2.0$ & [8] & $176.5 \pm 2.7$ & [8] \\
\hline \multirow{4}{*}{$\begin{array}{l}\text { Caput proximal } \\
\text { Epithelial height } \\
(\mu \mathrm{m})\end{array}$} & & & & & & & \\
\hline & Control & $18.5 \pm 0.5$ & [9] & $24.9 \pm 0.5$ & [8] & $23.5 \pm 0.8$ & [8] \\
\hline & DES 1.5 & $17.4 \pm 0.4$ & [10] & $23.7 \pm 1.7$ & {$[8]$ \# } & $22.9 \pm 0.6$ & [8] \\
\hline & DES 0.5 & $18.1 \pm 0.6$ & [9] & $26.0 \pm 0.6$ & [8] & $22.7 \pm 0.1$ & [8] \\
\hline \multirow{3}{*}{$\begin{array}{l}\text { Luminal diameter } \\
(\mu \mathrm{m})\end{array}$} & Control & $26.8 \pm 0.5$ & [9] & $68.3 \pm 0.8$ & [8] & $258.3 \pm 4.0$ & [8] \\
\hline & DES 1.5 & $27.4 \pm 0.8$ & [9] & $65.8 \pm 3.4$ & [8] & $243.1 \pm 4.7$ & [8]* \\
\hline & DES 0.5 & $27.5 \pm 0.3$ & [7] & $69.6 \pm 1.9$ & [8] & $245.7 \pm 7.1$ & [8] \\
\hline \multirow{3}{*}{$\begin{array}{l}\text { Tubular diameter } \\
(\mu \mathrm{m})\end{array}$} & Control & $63.9 \pm 1.3$ & [8] & $114.7 \pm 3.2$ & [10] & $305.3 \pm 4.5$ & [6] \\
\hline & DES 1.5 & $62.2 \pm 0.5$ & [9] & $113.3 \pm 2.6$ & [9] & $289.0 \pm 1.8$ & [8] * \\
\hline & DES 0.5 & $63.8 \pm 1.4$ & [7] & $120.8 \pm 3.7$ & {$[10]$} & $291.6 \pm 7.0$ & {$[8]$} \\
\hline \multirow{4}{*}{$\begin{array}{l}\text { Cauda proximal } \\
\text { Epithelial height } \\
(\mu \mathrm{m})\end{array}$} & & & & & & & \\
\hline & Control & $19.8 \pm 0.5$ & [9] & $35.6 \pm 0.7$ & [7] & $19.1 \pm 0.7$ & [8] \\
\hline & DES 1.5 & $18.9 \pm 0.3$ & [9] & $34.9 \pm 1.6$ & [7] & $18.5 \pm 3.0$ & [8] \\
\hline & DES 0.5 & $19.0 \pm 0.4$ & [7] & $35.5 \pm 0.8$ & {$[10]$} & $19.6 \pm 0.5$ & [8] \\
\hline \multirow{3}{*}{$\begin{array}{l}\text { Luminal diameter } \\
(\mu \mathrm{m})\end{array}$} & Control & $22.4 \pm 0.5$ & [9] & $43.7 \pm 0.8$ & [7] & $249.8 \pm 1.9$ & [8] \\
\hline & DES 1.5 & $22.0 \pm 0.4$ & [9] & $44.0 \pm 0.6$ & [7] & $231.0 \pm 1.9$ & [8] * \\
\hline & DES 0.5 & $21.7 \pm 0.4$ & [7] & $43.6 \pm 1.0$ & {$[10]$} & $244.8 \pm 2.6$ & [8] \\
\hline \multirow{3}{*}{$\begin{array}{l}\text { Tubular diameter } \\
(\mu \mathrm{m})\end{array}$} & Control & $62.1 \pm 0.8$ & [9] & $115.0 \pm 1.4$ & [7] & $288.1 \pm 3.8$ & [8] \\
\hline & DES 1.5 & $59.3 \pm 0.5$ & [9] * & $113.9 \pm 2.9$ & [7] & $268.2 \pm 4.2$ & [8]* \\
\hline & DES 0.5 & $60.0 \pm 1.0$ & [7] & $114.8 \pm 1.9$ & {$[10]$} & $254.1 \pm 7.2$ & [8] \\
\hline \multirow{4}{*}{$\begin{array}{l}\text { Cauda distal } \\
\text { Epithelial height } \\
(\mu \mathrm{m})\end{array}$} & & & & & & & \\
\hline & Control & $23.0 \pm 0.6$ & [9] & $30.6 \pm 1.2$ & [8] & $16.2 \pm 0.3$ & [8] \\
\hline & DES 1.5 & $22.1 \pm 0.4$ & [9] & $34.0 \pm 1.4$ & [8] & $16.7 \pm 0.1$ & [8] \\
\hline & DES 0.5 & $22.4 \pm 0.5$ & [8] & $31.4 \pm 1.2$ & [8] & $17.0 \pm 0.3$ & [8] \\
\hline \multirow{3}{*}{$\begin{array}{l}\text { Luminal diameter } \\
(\mu \mathrm{m})\end{array}$} & Control & $30.7 \pm 0.7$ & [9] & $89.4 \pm 4.4$ & [8] & $354.6 \pm 6.7$ & [8] \\
\hline & DES 1.5 & $28.2 \pm 0.5$ & [9] * & $72.7 \pm 6.2$ & [9] & $337.0 \pm 10.7$ & [8] \\
\hline & DES 0.5 & $30.2 \pm 0.8$ & [8] & $82.3 \pm 4.6$ & [7] & $334.5 \pm 10.5$ & [8] \\
\hline \multirow{3}{*}{$\begin{array}{l}\text { Tubular diameter } \\
(\mu \mathrm{m})\end{array}$} & Control & $76.8 \pm 1.4$ & [9] & $150.6 \pm 3.6$ & [9] & $387.2 \pm 6.2$ & [8] \\
\hline & DES 1.5 & $72.5 \pm 1.1$ & [9] * & $140.7 \pm 4.3$ & [9] & $370.6 \pm 10.8$ & [8] \\
\hline & DES 0.5 & $75.2 \pm 1.2$ & [8] & $145.2 \pm 3.6$ & [7] & $368.7 \pm 10.1$ & [8] \\
\hline
\end{tabular}

[ ] : No. of samples

* : Significant difference from control values $(\mathrm{p}<0.05)$.

\# : Significant difference from DES 0.5 group $(\mathrm{p}<0.05)$. 
Effects of DES on the development of the male reproductive system.

tion of testosterone, masculinizes the developing preoptic area; circulating estrogen, derived from the maternal circulation, is bound by $\alpha$-fetoprotein, and the $\alpha$-fetoprotein is thought to prevent circulating estrogen from affecting the developing brain (Arnold and Gorski, 1984). On day 18 of gestation, male fetal rats exhibit a surge of testosterone (Weisz and Ward, 1980); these higher testosterone levels presumably lead to formation of the higher estrogen levels in male brains, and subsequently to the estrogen-dependent sex differences observed in this region. The volume of SDN-POA of the rat brain is several-fold greater in adult males than that in adult females (Gorski et al., 1978). When female rats were treated pre- and postnatally with testosterone or with DES they became anovulatory and their SDN-POA developed to a size equivalent to that of normal males. Identical treatment of male rats had no influence on SDN-POA volume (Döhler et al., 1984). In agreement with previous reports, the volume of SDN-POA in male rats in the control group was approximately twice as large as that in female rats. Also, prenatal treatment with DES increased the volume of SDN-POA in 6-week-old female offspring in a dose-dependent manner, but did not influence that in male offspring. It has been reported that since endogenous testosterone has completely masculinized the central nervous system in males, the addition of DES does not further increase the volume of SDN-POA. Thus, in this study, the administration of DES, an exogenous estrogen, failed to significantly increase the volume of SDN-POA in males over that in the control group. The administration of DES significantly increased the volume of SDN-POA in females, but not in males, suggesting that the dose of DES administered was not sufficient for masculinizing SDN-POA. Therefore, the failure of DES treatment to alter the volume of SDN-POA in males in the DES 1.5 group suggests that the treatment was not sufficient for completely inhibiting the pre- or postnatal secretion of testosterone, and that DES has little or no inhibitory effect on the morphological end-

Table 5. Effect of prenatal exposure to DES on the GnRH recceptor mRNA level in pituitary from male offspring measured by semiquantitative RT-PCR.

\begin{tabular}{ccc}
\hline Group & \multicolumn{2}{c}{ GnRH mRNA expression } \\
\hline Control & $100.0 \pm 9.3$ & {$[5]$} \\
DES 0.5 & $100.0 \pm 29.4$ & {$[5]$} \\
DES 1.5 & $93.4 \pm 17.5$ & {$[5]$} \\
\hline
\end{tabular}

point of the male central nervous system.

The administration of DES to newborn or mature rats has been reported to increase germ cell apoptosis (Atanassova et al., 2000; Nair and Shaha, 2003). On the other hand, it has been reported that the administration of DES to adult rats does not influence spermatogenesis or sperm morphology (Goyal et al., 2001), and that DES administration increases FSH levels, promoting spermatogenesis (Atanassova et al., 1999). It has been reported that when rats are fed DES in drinking water during pregnancy or immediately after delivery, the offspring have decreased spermatogenesis, but sperm morphology and the spermatogenesis cycle do not change (Sharpe et al., 1995). However, no other studies have reported the effects of maternally administered DES on spermatogenesis in the offspring. Testosterone is the predominant androgen involved in the regulation of normal spermatogenesis in the rat, due to its high intratesticular concentration (Wright and Frankel, 1979), and is known to preferentially induce the conversion of round spermatids between stages VII and VIII (O'Donnel et al., 1994, 1996). The content of androgen receptors (AR) is maximal in Sertoli cells at stages VII-VIII (Shan et al., 1995). In the present study, at 6 weeks after birth, the decrease in the level of testosterone did not inhibit the conversion of round spermatids between stages VII and VIII. However, at 15 weeks, the percentages of stages IV and/or V seminiferous tubules increased in the DES groups and the percentages of stages IX and XI tubules decreased in the DES 1.5 group. We speculated that the low level of testosterone in the immature period reflected the cycles of spermatogenesis in adulthood.

A study reported that the oral administration of DES $(30 \mu \mathrm{g} / \mathrm{kg} /$ day) to rats at $11-18$ days of pregnancy reduced the weight of the epididymides after birth (Hossani et al., 2001). In this study, the prenatal administration of DES tended to reduce the epididymis weight. Although this study used a lower dose of DES compared with that in the above-cited study, we speculate that DES has the effect of retarding epididymis development. In addition, a study reported that decreased testosterone concentrations speed up the passage of sperms through the epididymis (Sujarit and Pholpramool, 1985); therefore, the epididymis weight decrease may have been influenced not only by the direct action of DES on the epididymis but also by a decrease in the amount of the sperm accumulated in the epididymides.

Previous reports have demonstrated that the administration of DES in the newborn period dilates 
M. YAMAMOTO et al.

the rete testis and efferent duct luminal areas, reducing the height of epididymal tubule epithelial cells (Rivas et al., 2002), and that it strongly inhibits the expression of AR in the epididymides (McKinnell et al., 2001). An immunohistochemical study of the expression of AR in prenatal and postnatal testes and epididymides has shown that AR is present from the 15th day of gestation in testicular Leydig cells and mesonephric tissue (You and Sar, 1998). The epithelium in the mesonephros-derived tissues, including the rete testis and epididymis, appears to exhibit a higher capacity to express AR than the rest of the testicular tissues (You and Sar, 1998). Therefore, we speculate that DES-induced low levels of testosterone more strongly influence the epididymides, resulting in more marked retardation of epididymal than testicular development at the histological level. Similarly, we speculate that low levels of testosterone influence the prostate, a mesonephrosderived tissue, resulting in an event, that is, weight loss.

\section{ACKNOWLEDGMENT}

This work was supported by a fund for the Longrange Research Initiative from the Japan Chemical Industry Association.

\section{REFERENCES}

Arai, Y., Mori, T., Suzuki, Y. and Bern, H.A. (1983): Long-term effects of perinatal exposure to sex steroid and diethylstilbestrol on the reproductive system of male mammals., Int. Rev. Cytol., 84, 235-268.

Arnold, A.P. and Gorski, R.A. (1984): Gonadal steroid induction of structural sex differences in the central nervous system. Annu. Rev. Neurosci., 7, 413-442.

Atanassova, N., McKinnell, C., Walker, M., Turner, K.J., Fisher, J.S., Morley, M., Millar, M.R., Groome, N.P. and Sharpe, R.M.(1999): Permanent effects of neonatal estrogen exposure in rats on reproductive hormone levels, Sertoli cell number, and the efficiency of spermatogenesis in adulthood. Endocrinology, 140, 5364-5373.

Atanassova, N., McKinnell, C., Turner, K.J., Walker, M., Fisher, J.S., Morley, M., Millar, N.R., Groome, N.P. and Sharpe, R.M. (2000): Comparative effects of neonatal exposure of male rats to potent and weak (environmental) estrogens on spermatogenesis at puberty and rela- tionship to adult testis size and fertility: Evidence for stimulatory effects of low estrogen levels. Endocrinology, 141, 3898-3907.

Atanassova, N., McKinnell, C., Williams, K., Turner, K.J., Fisher, J.S., Saunders, P.T., Millar, M.R. and Sharpe, R.M. (2001): Age-, cell- and region-specific immunoexpression of estrogen receptor $\alpha$ (but not estrogen $\beta$ ) during postnatal development of the epididymis and vas deferens of the rat and disruption of this pattern by neonatal treatment with diethylstilbestrol. Endocrinology, 142, 874-886.

Boylan, E.S. (1978): Morphological and functional consequences of prenatal exposure to diethylstilbestrol in the rat. Biol.Reprod., 19, 854-863.

Döhler, K.-D., Cooquelin, A., Davis, F., Hines, M., Shryne, J.E. and Gorski, R.A. (1984): Pre- and postnatal influence of testosterone propionate and diethylstilbestrol on differentiation of the sexually dimorphic nucleus of the preoptic area in male and female rats. Brain Res., 302, 291295.

Gorski, R.A., Gordon, J.H., Shryne, J.E. and Southam, A.M. (1978): Evidence for a morphologic sex difference within the medial preoptic area of the rat brain. Brain Res., 148, 333-346.

Goyal, H.O., Braden, T.D., Mansour, M., Williams, C.S., Kamaledin, A. and Srivastava,K.K. (2001): Diethylsilbestrol-treated adult rats with altered epididymal sperm numbers and sperm motility parameters, but without alterations in sperm production and sperm morphology. Biol. Reprod., 64, 927-934.

Goyal, H.O., Robateau, A., Braden, T.D., Williams, C.S., Srivastava, K.K. and Ali, K. (2003): Neonatal estrogen exposure of male rats alters reproductive functions at adulthood. Biol. Reprod., 68, 2081-2091.

Haavisto, T., Nurmela, K., Pohjanvirta, R., Huuskonen, H., ElGehani, F. and Paranko, J. (2001): Prenatal testosterone and luteinizing hormone levels in male rats exposed during pregnancy to 2,3,7,8-tetrachlorodiabenzo- $p$ dioxin and diethylstilbestrol. Mol. Cell. Endocrinol., 178, 169-179.

Herbst, A.L. and Bern, H.A. (1981): Developmental Effects of Diethylstilbesrol (DES) in Pregnancy. Thieme-Stratton, New York.

Hermo, L., Oko, R. and Robaire, B. (1992): Epithelial cells of the epididymis show regional variations with respect to the secretion of endocytosis of 
Effects of DES on the development of the male reproductive system.

immobilin as revealed by light and electron microscope immunocytochemistry. Anat. Rec., 232, 202-220.

Hess, R.A. (1990): Quantitative and qualitative characteristics of the stages and transitions in the cycle of the rat seminiferous epithelium: Light microscopic observations of perfusion-fixed and plastic-embedded testes. Biol. Reprod., 43, 525542.

Hossani, A., Dalgaad, M., Vinggaad, A.M., Frandsen, H. and Larsen, J.J. (2001): In utero reproductive study in rats exposed to nonylphenol. Reprod. Toxicol., 15, 537-543.

Kaplan, N.M. (1959): Male pseudohemaphrodism: Report of a case with observations on pathogenesis. N. Engl. J. Med., 261, 641-644.

McKinnell, C., Atanassova, N., Williams, K., Fisher, J.S., Walker, M., Turner, K.J., Saunders, T.K. and Sharpe, R.M. (2001): Suppression of androgen action and the induction of gross abnormalities of the reproductive tract in male rats treated neonatally with diethylstilbestrol. J. Androl., 22, 323-338.

McLachlan, J.A., Newbold, R.R. and Bullock, B. (1975): Reproductive tract lesions in male mice expressed prenatally to diethylstilbestrol. Science, 190, 991-992.

Nair, R. and Shaha, C. (2003): Diethylstilbestrol induces rat spermatogenic cell apoptosis in vitro through increased expression of permatogenic cell Fas/FasL system. J.Biol. Chem., 278, 64706481.

O'Donnel, L., McLachlan, R.I., Wreford, N.G. and Robertson, D.M. (1994): Testosterone promotes the conversion of round spermatid between stages VII and VIII of the rat spermatogenic cycles. Endocrinology, 135, 2608-2614.

O'Donnel, L., McLachlan, R.I., Wreford, N.G., de Kretser, D.M. and Robertson, D.M. (1996): Testosterone withdrawal promotes stage-specific detachment of round spermatids from the rat seminiferous epithlium. Biol. Reprod., 55, 895901.

Rivas, A., Fisher, J.S., McKennel, C., Atanassova, N. and Sharpe, R.M. (2002): Induction of reproductive tract developmental abnormalities in the male rat by lowering androgen production or action in combination with low dose of diethylstilbestrol: Evidence for importance of the androgen-estrogen balance. Endocrinology, 143, 4797-4808.
Roth, C.M., Schricker, M., Lakimek, M., Strege, A., Heiden, I., Luft, H., Munzel, U., Wuttke, W. and Jarry, H. (2001): Autoregulation of gonadotropin releasing hormone system during puberty: Effects of antagonistic versus agonistic GnRH analogues in a female rat model. J. Endocrinol., 169, 361-371.

Shan, L.X., Hardy, J.F. and Catterall, M.P. (1995): Effects of luteinizing hormone (LH) and androgen on steady state levels of messenger ribonucleic acid for LH receptors, androgen receptors, and steroidogenic enzymes in rat Leydig cell progenitors in vivo. Endocrinology, 136, 16861693.

Sharpe, R.M. and Skakkebeak, K.E. (1993): Are oestrogens involved in falling sperm counts and disorders of the male reproductive tract? Lancet., 341, 1392-1395.

Sharpe, R.M., Fisher, J.S., Millar, M.M., Jobling, S. and Sumpter, J.P. (1995): Gestational and lactational exposure of rats to xenoestrogens results in reduced testicular size and sperm production. Environ. Health Perspect., 103, 1136-1143.

Sharpe, R.M., Atanassova, N., Mckinnel, C., Parte, P., Turner, K.J., Fisher, J.S., Kerr, J.B., Groome, N.P., Macpherson, S., Millar, M.R. and Saunders, P.T.K. (1998): Abnormalities in functional development of the Sertoli cells in rats reacted neonatally with diethylstilbestrol: A possible role for estrogens in Sertoli cell development. Biol. Reprodct., 59, 1084-1094.

Steel, R.G.D. and Torrie, J.H. (1980): Principles and Procedures of Statistics, 2nd ed. McGraw-Hill Book Company, New York.

Sujarit, S. and Pholpramool, C. (1985): Enhancement of sperm transport through the rat epididymis after castration. J. Reprod. Fertil., 74, 497-502.

Traina, M.E., Rescia, M., Urbani, E., Mantovani, A., Marci, C., Ricciardi, C., Stazi, A.V., Fazzi, P., Cordelli, E., Eleuteri, P., Leter, G. and Spano, M. (2003): Long-lasting effects of lindane on mouse spermatogenesis induced by in utero exposure. Reptod. Toxicol., 17, 25-35.

Walker, N.J., Portier, C.J., Lax, S.F., Crofts, F.G., Li, Y., Lucier, G.W. and Sutter, T.R. (1999): Characterization of the dose-response to CYP1B1, CYP1A1, and CYP1A2 in the liver of female Sprague-Dawley rats following chronic exposure to 2,3,7,8-tetrachlorodibenzo- $p$-dioxin. Toxicol. App. Pharmacol., 154, 279-286.

Weisz, J. and Ward, I.L. (1980): Plasma testosterone 
and progenserone titers of pregnant rats, their male and female fetuses, and neonatal offspring. Endocrinology, 106, 306-316.

Wright, W.W. and Frankel, A.I. (1979): Endogeneous androgen concentrations in nuclei isolated from seminiferous tubules of mature rat testes. J. Steroid Biochem., 10, 633-640.

Yamamoto, M., Shirai, M., Sugita, K., Nagai, N., Miura, Y., Mogi, R., Yamamoto,K., Tamura,A. and Arishima, K. (2003): Effects of maternal exposure to diethylstilbestrol on the development of the reproductive system and thyroid function in male and female rat offspring. J. Toxicol. Sci., 28, 385-394.

You, L. and Sar, M. (1998): Androgen receptor expression in the testes and epididymides of prenatal and postnatal Sprague-Dawley rats. Endocrine, 9, 253-261. 